\title{
Effect of compost extract and microelements on growth, yield and active ingredients of Trigonella foenum-graecum $\mathrm{L}$. plants
}

\author{
Khater Rania M. R.* \\ Medicinal and Aromatic Plants Department, Desert Research Center, Cairo, Egypt
}

\begin{abstract}
This investigation was carried out to study the effect of spraying with compost extract and different chelated microelement forms, on the production seed yield, oil production and active substances of fenugreek plants under North Sinai conditions. The results showed that, all treatments recorded a highly significant increase for all studied parameters in both seasons compared with the control treatment. The highest values of all parameters the combining compost extract plus M. E. Humic form. Percentage of increase seed yield was ranged from 30 to $29 \%$, and in fixed oil, the increase reached 131 to $116 \%$ in the first and second season, respectively. Also, there was a significant increase in the active substances inside the plant, and found a significant increase when plant treated with compost extract plus M. E. Humic form, where the percentage of increase in mucilage, protein and trigonelline was 128,68 and $70 \%$ in the first season, while the increase rate was $99,64,64 \%$ in the second season.
\end{abstract}

Keywords: compost extract, microelements, humic, EDTA, fenugreek, trigonelline. 


\section{Introduction}

Fenugreek (Trigonella Foenum-graecum L.) belongs to the family of Leguminosae, it's a herbal plant, roots with nodal bacteria. Plant multiples with seeds containing active substances that have medical properties. The seeds of fenugreek contain mucilage and contain trigonelline, Choline, which enters the metabolic process metabolism. These substances are found in the oil of the fenugreek which is attributed to the medicinal effect of the seeds of the fenugreek plant. The seeds also contain saponins, colored materials and nicotinic acid. The plant is rich in proteins, sugars and fats, which makes its nutritional value very high. It contains salts, $\mathrm{Fe}, \mathrm{Ca}, \mathrm{P}$ and some vitamins such as $\mathrm{D}$ and $\mathrm{C}$ (Alaghemand et al., 2017; Bukhari et al., 2008). Fenugreek used for medical purposes. It has been known since ancient times the effect of seeds on milk produsing for women at the time of breastfeeding, it also helps to stimulate urine and menstruation for women. The mucilage in fenugreek seeds helps to soften sore throat, treat asthma, shortness of breath, appetizer and helps digestion (Alaghem et al. 2017; Bukhari et al., 2008; Haouala et al., 2008; Kaviarasan et al., 2007; Zuppa et al., 2010). Relieve constipation helps in the digestion, protection of colon infections because fenugreek plant has anti-inflammatory properties (Ke et al., 2012; Bae, 2014), reduces blood cholesterol, triglyceride (Bordia et al., 1997) increases sexual ability in men (Sindhu et al., 2012). Foliar fertilization is one of the most suitable methods used in adding microelements to the plant, where the plant extends its needs of nutrients through the vegetable total and not by the roots, where research has shown that all the nutrients absorbed by the roots can be absorbed by leaves, stems and fruits. The absorption of micro elements by leaves is usually more efficient and faster than absorption by the roots. Especially when soil conditions are unsuitable for absorption such as soil $\mathrm{pH}$ rise and soil nutrient loss by washing, drainage and other factors that affect the availability of elements for absorption (Baloch et al. 2008; Bernal et al., 2007). Some experiments and studies studied the effect of foliar fertilization on the ring plant to increase the plant growth, productivity and active substances on plants under study (Amal et al., 2015; Boghdady, 2017; Srinivassan, 2006). Egypt's sustainable development plan 2030 state issued a draft law to regulate organic agriculture as a result of the harm to humans and the environment from the use of chemical fertilizers and its attendant to reduce soil fertility and high desertification rates in agricultural lands and the spread of serious diseases, cancer and hepatitis, etc. The project aims to support the state's plan to produce healthy food, by reducing the use of pesticides and chemical fertilizers and replacing them with alternatives to organic fertilizers. The compost extract is considered to be an organic fertilizer resulting from plant residue and added to it some sugar materials, yeasts and microbes that increase the availability of the elements in the soil and also increase soil fertility as to reduces the use of chemical fertilizers by $50 \%$ (Rehab Heba, 2018) thus reduces the damage resulting 
from their use on environment, human and animal (Atiyeh et al., 2002; Khan et al., 2010). Compost extract is the liquid produced by the composted soil after leaving for about 14 days as this liquid contains soluble nutrients, microorganisms, phytohormones and growth regulators. All these components directly and indirectly affect plants through the surrounding area of the roots, where it has a role in improving soil properties and supply the plant with nutrients and protects the roots and other plant tissues from pathogens. Some studies on application plants with compost extract (Ezz El-Din Azza and Hendawy, 2010; Heba et al., 2018; Haggag Laila et al. 2014; Lal et al., 2015). These studies gave positive results to produce the best vegetative growth and a fresh and dry one for plants and acres, as well as an increase in the percentage and yield of oil and active substances for plants under study. The objective of the study was to investigate effect of foliar fertilization on seed yield, vegetative growth, and active substances of fenugreek plant using various sources of micro-elements mixed with compost extract.

\section{Materials and methods}

The research was carried out in two successive seasons i.e. 2016- 2017 and 2017-2018 at Baluza Research Station, Desert Research Center, Egypt on Fenugreek plants, the research area is located on $30^{\circ} 3^{\prime} 0^{\prime \prime} \mathrm{N}, 32^{0} 36^{\prime} 0^{\prime \prime} \mathrm{E}$. The research was conducted to study the effect of different chelated microelements forms and spraying with compost extract and their interaction on seed yield, oil production and the active ingredients of Trigonella foenamgraecum L. Fenugreek seeds were obtained from the Research Center of Medicinal and Aromatic Plants, Dokki, Giza, Egypt. The seeds were sown on November $15^{\text {th }}$ and $10^{\text {th }}$ in the first and second seasons, respectively. After 21 days of planting, seedlings were thinned to two plants per hill. The experimental field was drip irrigated and normal agricultural practices were applied as required. The physical and chemical properties of soil used are shown in Table (1) according to Page et al. (1981).

Table (1): Physical and chemical properties of the experimental soil of Baluza Research Station, Desert Research Center, North Sinai governorate, Egypt.

\begin{tabular}{|c|c|c|c|c|c|c|c|c|c|c|c|c|c|c|c|c|}
\hline \multicolumn{3}{|c|}{$\begin{array}{c}\text { Particle size } \\
\text { distribution }(\%)\end{array}$} & \multirow{3}{*}{$\begin{array}{l}\text { Texture } \\
\text { class }\end{array}$} & \multirow{3}{*}{$\begin{array}{c}\mathrm{EC} \\
\mathrm{dSm}-1\end{array}$} & \multirow{3}{*}{$\mathrm{pH}$} & \multicolumn{8}{|c|}{ Soluble ions (meq/l) } & \multirow{2}{*}{\multicolumn{3}{|c|}{$\begin{array}{c}\text { Available } \\
\text { nutrients } \\
\text { (ppm) }\end{array}$}} \\
\hline \multirow{2}{*}{ Sand } & \multirow{2}{*}{ Silt } & \multirow{2}{*}{ Clay } & & & & \multicolumn{4}{|c|}{ Cations } & \multicolumn{4}{|c|}{ Anions } & & & \\
\hline & & & & & & $\mathrm{Ca}^{+2}$ & $\mathrm{Mg}^{+2}$ & $\mathrm{Na}^{+1}$ & $\mathrm{~K}^{+1}$ & $\mathrm{CO}^{-3}$ & $\mathrm{HCO}^{-3}$ & $\mathrm{SO}^{-4}$ & $\mathrm{Cl}^{-1}$ & $\mathrm{~N}$ & $\mathrm{P}$ & $\mathrm{K}$ \\
\hline 90 & 5 & 5 & Sandy & 1.37 & 8.20 & 1.8 & 2.1 & 1.5 & 0.09 & - & 3.5 & 0.84 & 1.51 & 60 & 3.65 & 144 \\
\hline
\end{tabular}

The plot was $3 \times 4 \mathrm{~m}^{2}$ with 100 plants per plot, the rows were $40 \mathrm{~cm}$ apart whereas the hills were $30 \mathrm{~cm}$ apart ( 35000 plants /feddan) $($ feddan $=0.420$ hectares $=$
1.037 acres). The experiment was set up in a split plot design including 8 treatments with three replicates, the main plot was sprayed with compost extract, 
while the sub-plot was sprayed with chelated microelements forms. The treatments that were sprayed with compost extract include a control treatment and a compost-extract sprayed treatment, whereas the treatments of the different chelated microelements forms comprised a control, mineral form, EDTA form and humic form. The source of compost extract was made by Soil Fertility and Microbiology department, Desert Research Center according to Heba et al. (2018). The different chelated microelements forms composed of a mixture of some microelements i.e. Fe, $\mathrm{Zn}, \mathrm{Mn}$ and $\mathrm{Cu}$ in chelated forms of humic acid and EDTA. All plants were sprayed after 35 and 70 days from date of sowing, while the untreated plants (control) were sprayed with tap water.

\subsection{The recorded data}

\subsubsection{Seed yield}

Fenugreek pods were harvested after 150 days from seed sowing in both seasons to determine the weight of seeds ( $\mathrm{g} / \mathrm{plant}$ ) and $(\mathrm{kg} / \mathrm{feddan})$ which were calculated as follows:

Seed yield $/$ feddan $=$ seed yield $/$ plant $\times$ number of plants /feddan (28000 plants) for each treatment

\subsubsection{Oil yield}

Fenugreek seeds fixed oil was extracted using petroleum ether in a soxcelt system HT apparatus according to the methods of Hadi et al. (2018). Oil percentage and oil yield per plan $(\mathrm{g})$ and feddan $(\mathrm{Kg})$.

\subsubsection{Active ingredients}

\subsubsection{Mucilage percentage in seeds}

Mucilage percentage was determined in fenugreek seeds according to the method described by Kumar (2009).

\subsubsection{Protein percentage in seeds}

To determine protein content, the total nitrogen percentage in seed was determined according to the methods described by Abdel Moneim et al. (2008) and was multiplied by 6.25 to calculate protein percentage.

\subsubsection{Trigonelline seed content $(\mathrm{mg} / \mathrm{g})$}

Trigonelline seed content in fenugreek seed was determined by estimating the equation; trigonelline alkaloid = absorbance of test at $268 \mathrm{~nm} /$ absorbance of standard (Gorham, 1986). Then trigonelline content per plant (g) was calculated through multiply trigonelline percentage by seed yield per fenugreek plant.

\subsection{Statistical analysis}

Research data were statistically analyzed and the difference between the means of treatments was considered significant or highly significant when they were more than the test significant according difference (LSD) at 0.5 and 0.1 
significance levels respectively by using the computer program of statistic version (https://www.statistix.com/free-trial/).

\section{Discussion}

3.1 Effect of compost extract and different chelated microelements forms on seed yield

All treatments showed a highly significant increase in seed yield per plant $(\mathrm{g})$ and feddan $(\mathrm{kg})$ in both seasons compared with the control treatment (Figures 1 and 2). The highest values of seed weight resulted from combining compost extract with M. E. Humic form. The interaction between compost extract and M. E. Humic form increased seed weight per plant and per feddan by $30 \%$ and $29 \%$ in the first season and the second season, respectively. The interaction between compost extract and M. E. EDTA form significantly increased seed weight by $17 \%$ and $16 \%$ at the first season and the second season, respectively; meanwhile M. E. Humic form alone increased seed by $16 \%$ and $13 \%$, but the increase rate dropped to 12 $\%$ and $12 \%$ in the treatment of M. E. form alone during seasons, respectively. The difference between treatments with or without compost extract was significant in both seasons, but the difference between treatments with different chelated microelements forms was not significant in the second season. The obtained results are generally in harmony with those reported by Srinivassan (2006), Boghdady (2017) and Aishwath et al. (2018).

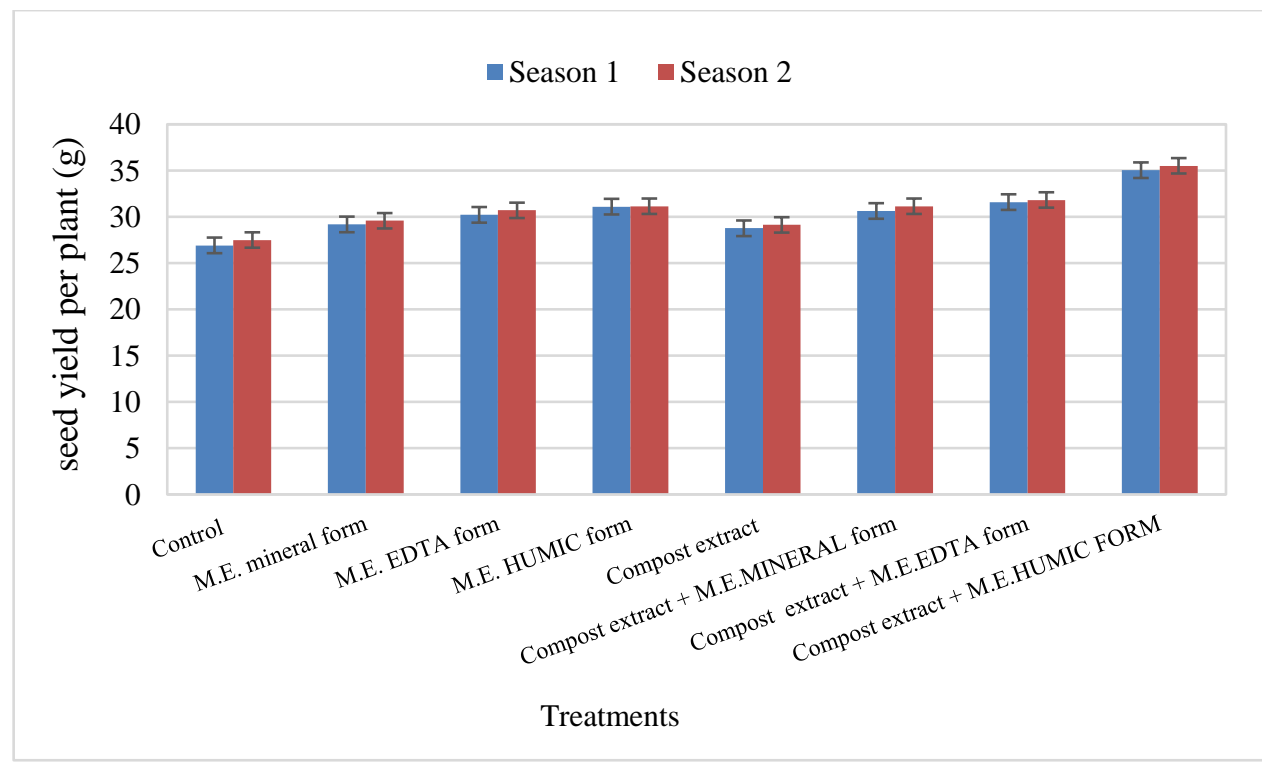

Figure (1): Effect of compost extract and different microelements froms on seed yield per plant (g) of fenugreek plants during 2016/2017 and 2017/2018 seasons. 


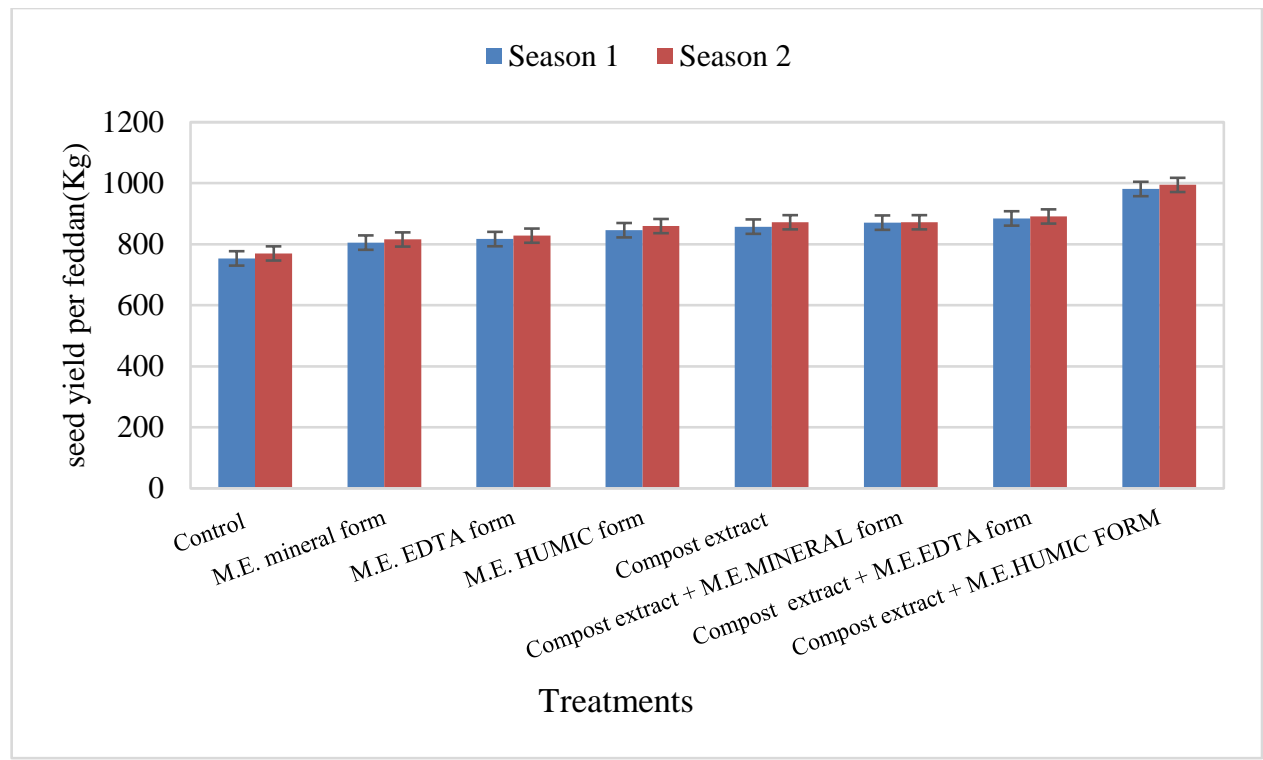

Figure (2): Effect of compost extract and different microelements froms on seed yield per feddan $(\mathrm{Kg})$ of fenugreek plants during 2016/2017 and 2017/2018 seasons.

\subsection{Fixed oil percentage in fenugreek seeds}

Fixed oil increased for all treatments compared with the control treatment (Figure 3). The interaction of compost extract and different chelated microelements indicated a significant high oil yield; the values were significantly high in both treatments, with and without compost extract, and the different chelates of microelements forms. The M. E. Humic form combined with compost extract increased fixed oil percentage by $131 \%$ and $116 \%$ in both seasons, respectively; while M. E. Humic form alone increased fixed oil percentage by $57 \%$ and $42 \%$, respectively. The combination between M. E. EDTA form and compost extract increased fixed oil percentage by $107 \%$ and $90 \%$ in both seasons, respectively; while the treatment of M. E. EDTA form alone increased fixed oil percentage by $47 \%$ and $36 \%$ in both seasons, respectively. The difference between treating plants with and without compost extract and different chelated M. E. forms was significant in both seasons. These results are in accordance with those obtained by (Amal et al., 2015; Boghdady, 2017).

\subsection{Oil yield per plant $(g)$ and feddan $(\mathrm{Kg})$}

Oil yield per plant and per feddan were significantly increased for all treatments; whereas compost extract combined with M. E. Humic form affected oil yield positively by an increase of $201 \%$ and $179 \%$ for the first and second seasons, respectively, while interacting M. E. 
EDTA form with compost extract respectively. There were significant resulted in an increase of oil yield by 143 values between the treatments with and $\%$ and $120 \%$ in both seasons, without compost extract application and respectively, meanwhile M. E. Humic different chelated microelements forms and EDTA forms alone increased oil in both seasons (Figures 4 and 5). Similar yield only by $114 \%, 89 \%, 67 \%$ and 58 results were obtained by Chhibba et al. $\%$ in the first and second seasons, (20070 and Lal et al. (2015).

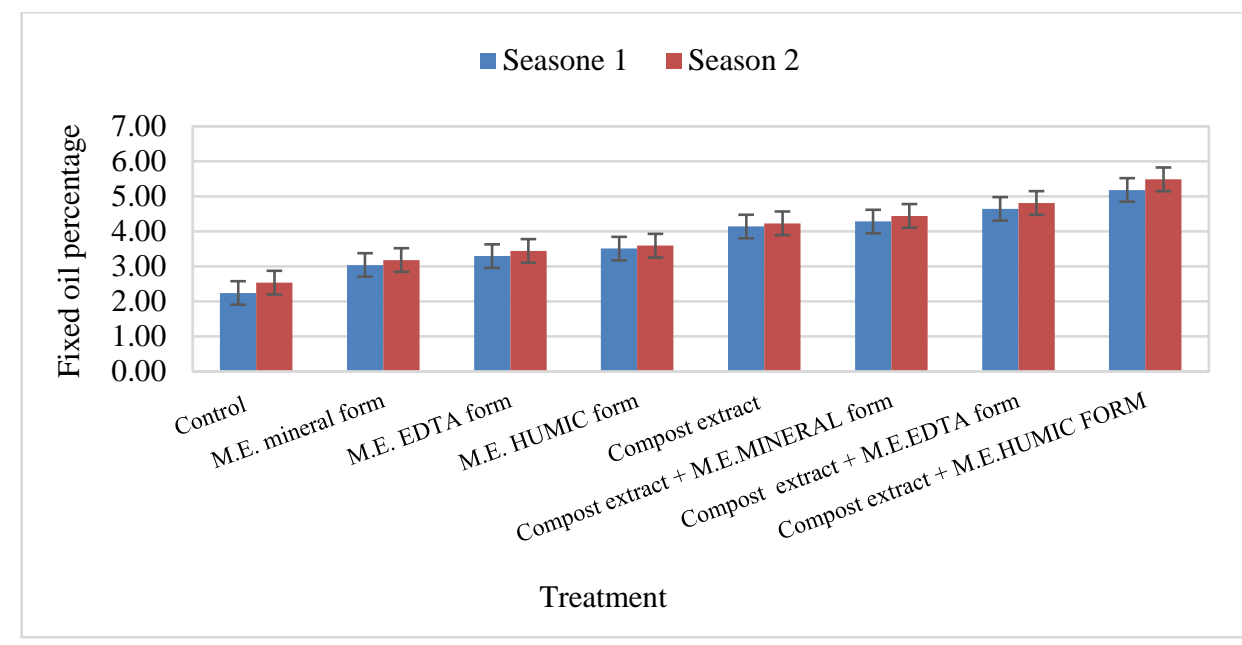

Figure (3): Effect of compost extract and defferant microdelements froms on fixed oil percentage of fenugreek seeds during 2016/2017 and 2017/2018 seasons.

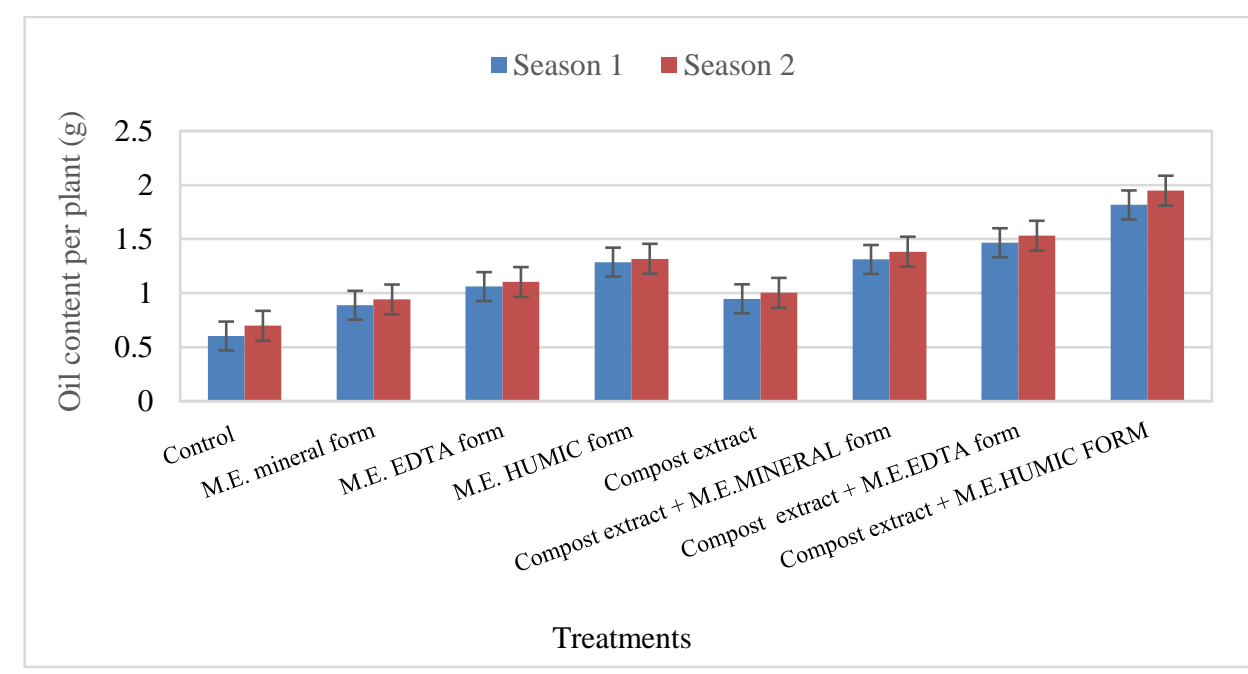

Figure (4): Effect of compost extract and different microelements froms on oil content per plant (g) of fenugreek seeds during 2016/2017 and 2017/2018 seasons. 


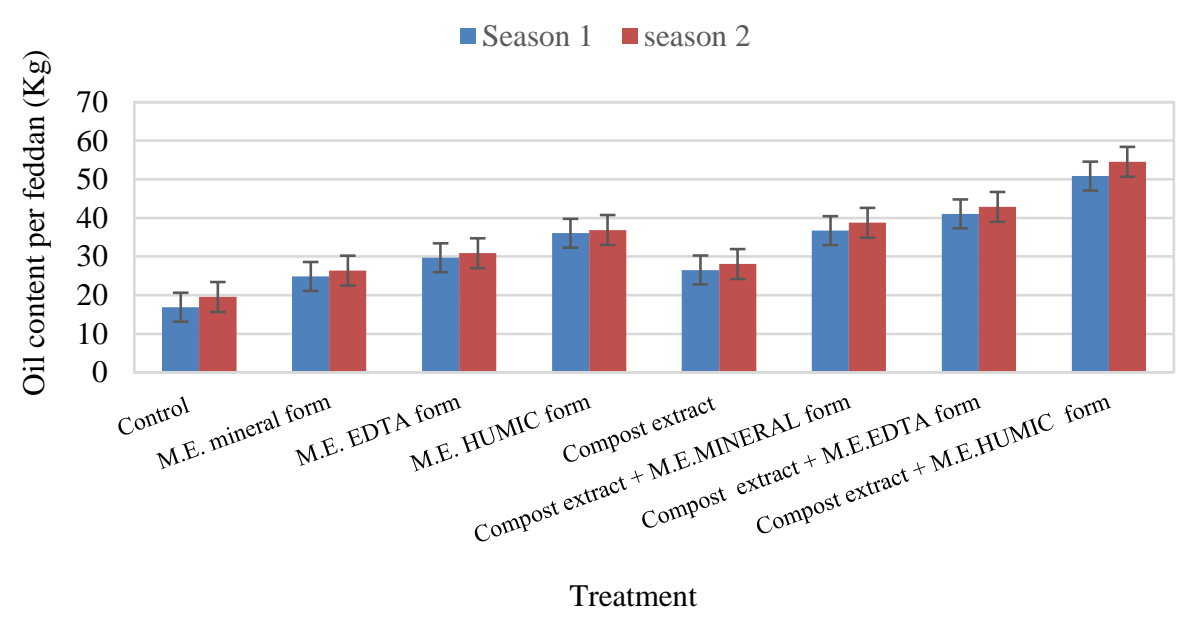

Figure (5): Effect of compost extract and different microelements froms on oil content per feddan $(\mathrm{Kg})$ of fenugreek seeds during 2016/2017 and 2017/2018 seasons.

\subsection{Active ingredients}

\subsubsection{Mucilage percentage}

Percentage of mucilage was significantly increased for all treatments in both seasons (Figure 6). The application of compost extract combined with M. E. Humic and EDTA forms significantly increased mucilage percentage by $(79 \%$ and $66 \%)$ and $(57 \%$ and $41 \%)$ in fenugreek seed during both seasons, respectively; while in applying $\mathrm{M}$. E. EDTA, mucilage percentage and seed yield increased by $20 \%$ and $16 \%$, respectively, and when applying M. E. Humic form, there was an increase of 32 $\%$ and $25 \%$ in both seasons, respectively. The difference between integrating compost extract (with and without) was significant as well as when applying different chelated M. E. forms. The obtained results are generally in harmony with those reported by Pariari et al. (2009), Sharma et al. (2014) and Rehab (2018).

\subsubsection{Protein content per plant seed ( $g$ )}

Treatments with and without applying compost extract increased protein content in plant seeds and the increase was highly significant with applying M. E. EDTA form by $28 \%$ and $26 \%$. The difference between M. E. EDTA form and compost extract was insignificant on the first season and significant in the second season. The combination of compost extract with M. E. Humic form significantly increased protein content in seeds by $68 \%$ and $64 \%$, the difference between M. E. Humic form and EDTA form when spraying with or without compost extract was significant, the difference between applying compost extract or without it and the different 
chelated microelements forms was highly were obtained by Heba et al. (2018), Ezz significant. (Figure 7). Similar results El-Din Azza and Hendawy (2010).

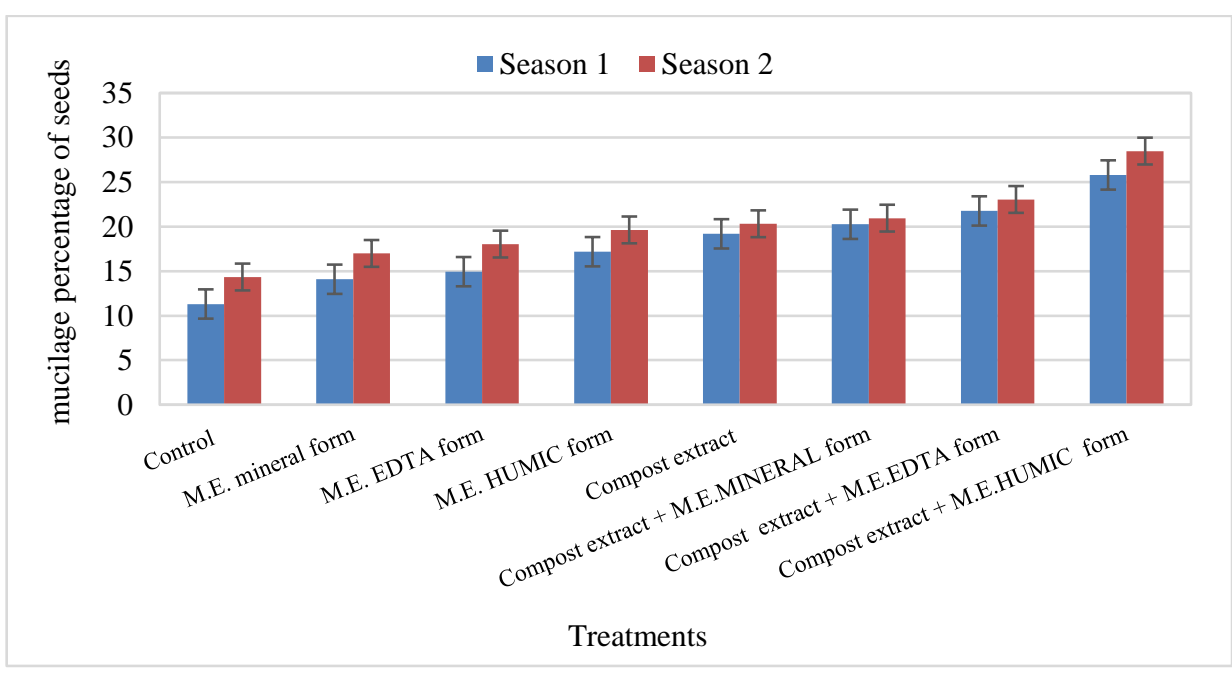

Figure (6): Effect of compost extract and different microelements froms on mucilage percentage of fenugreek seeds during 2016/ 2017 and 2017/2018 seasons.

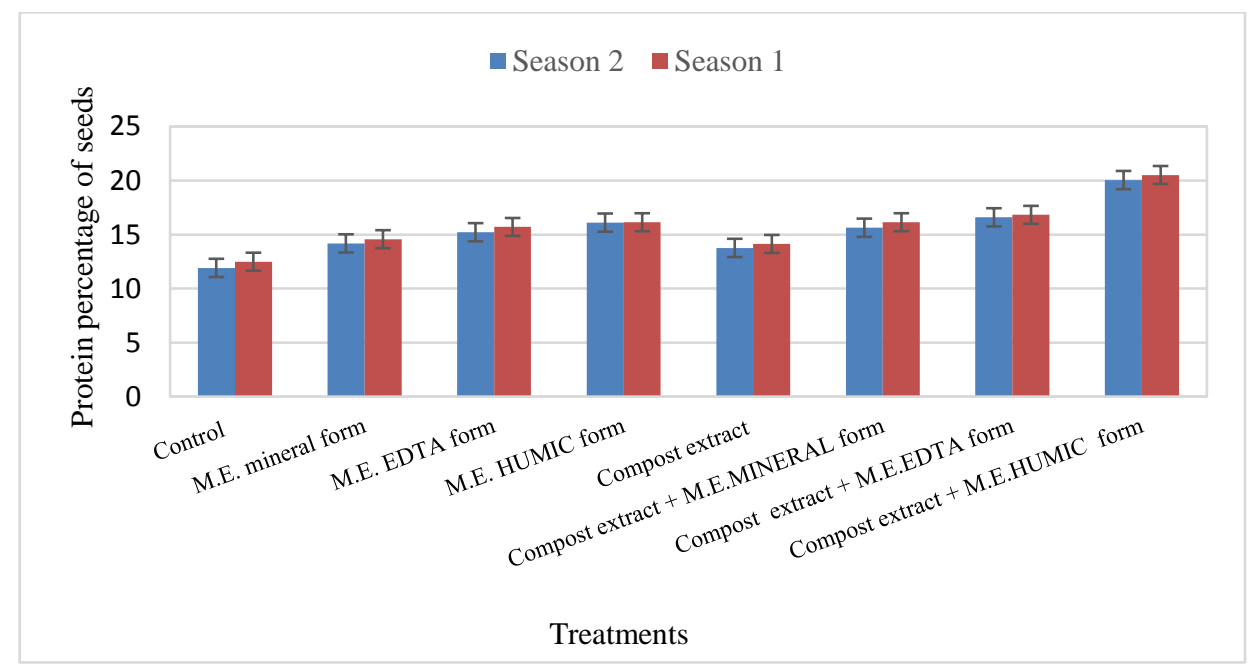

Figure (7): Effect of compost extract and defferante microdelements froms on protein percentage of Fenugreek seeds during 2016/2017 and 2017/2018 seasons.

3.4.3 Trigonelline content per plant $(\mathrm{mg} / \mathrm{g})$

Applying compost extract combined with
M. E. EDTA form highly increased the trigonelline content in fenugreek seeds by $39 \%$ and $35 \%$, while integrating 
compost extract with M. E. Humic form gave high rates by $70 \%$ and $67 \%$ in the first and second seasons, respectively. $\mathrm{M}$. E. as chelated Humic and EDTA form alone, increased seed content of trigonelline by (43\% and $39 \%)$ and (39
$\%$ and $35 \%$ in both seasons, respectively (Figure 8). There was a significant difference between applying the compost extract or without it, whereas there was a significant effect on trigonelline content per plant.

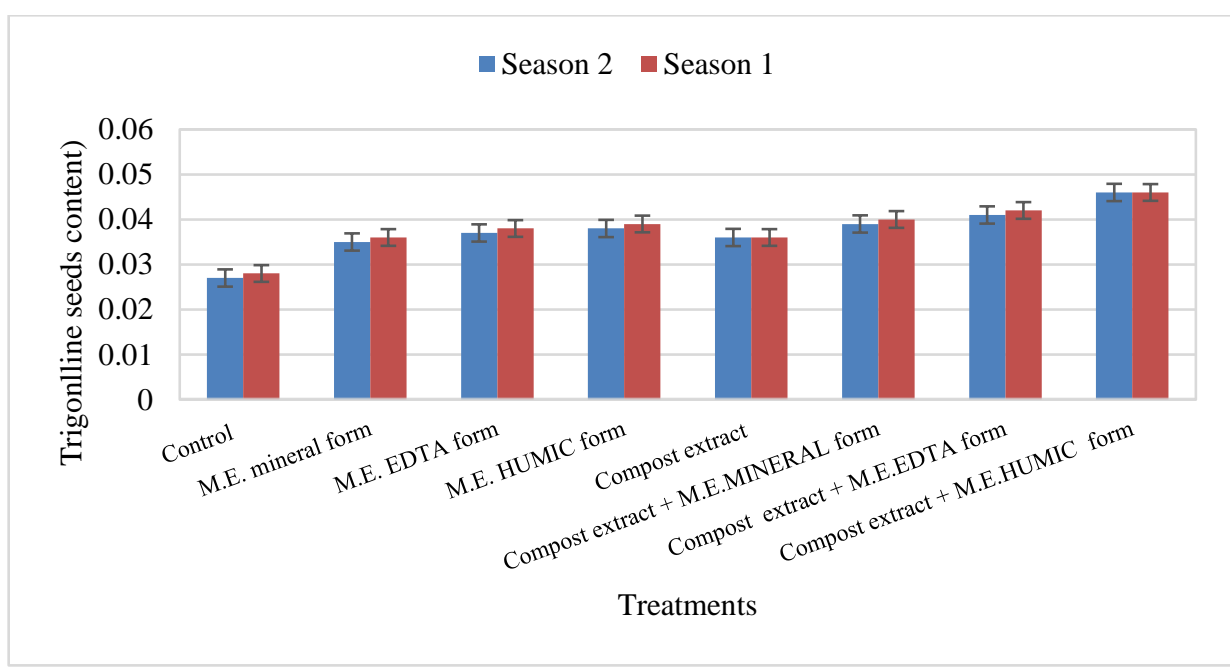

Figure (8): Effect of compost extract and differente microelements froms on trigonlline seeds content (mg/g) of fenugreek seeds during 2016/2017 and 2017/2018 seasons.

These results are in according to with those obtained by Scheuerell (2003), Gharib et al. (2008) and Haggag Laila et al. (2014).

\section{Discussion}

Although the plant needs of micronutrients in a small amount, the availability of these elements for the plant is important in obtaining the highest productivity from the plant. Micronutrients may be present in the soil, but in their non-soluble form, the plant does not benefit from them. Therefore, another source must be available to supply the plant to compensate for the deficiency in these elements. Leaf feeding is one of the most important and most successful methods of fertilization, as it makes it easier for the plant to absorb the elements in a soft form. Effect of the plants response to the absorption of micronutrients by foliar fertilization is due to the spray solution containing salts of some elements such as zinc, manganese, iron and copper, as this led to competition between the micronutrients ions mixed with the absorption sites in the leaves. The 
response of fenugreek plants to spraying with micronutrients and compost extract resulted in a significant increase in the seed and oil yield as well as the active substance. The results have shown an increase in the second season over the first season in the seed yield, oil production, and the active substance. Fenugreek may be attributed to spraying with microelements that increases the effectiveness of the added fertilizer because it acts as a catalyst for growth. Many studies have confirmed the importance of spraying with micronutrients, improving plant growth and increasing the productivity of fenugreek. Abd-Elghany Gehan et al. (2017), Rehab (2018) and Ibrahim (2019) pointed that micro-nutrients have an active role in many biological processes as they stimulate the formation of proteins and enzymes within the plant. They also stimulate the formation of chlorophyll to help in the transfer of sugars and carbohydrates and regulate the osmotic potential of cells. Compost extract with some nutrients, microorganisms and sugars. Treatment of plants with compost extract led to improve growth in many characters by increasing the effect of nutrient absorption, due to the superiority of the plant's absorption of compost extract through leaves and its effect on seed yield, oil production, and active substances within the fenugreek plant where an increase in seed productivity was observed. Fixed oil for plants and feddan also found an increase in the percentage of active substances in the plant such as fixed oil, protein, mucilage, and trigonelline. Similar results were obtained by Ibrahim Heba et al. (2018). The effect of increasing the production of fenugreek in the treatment compost extract plus M. E. humic form due to the role of mixing the muscular elements with the compost extract, which led to an increase in the effectiveness of the vital processes necessary for plant growth, as the compost extract contains microorganisms, humic acid and some sugars and micronutrients that led to an increase in nitrogen receptors, which led to an increase in the activity of enzymes that have a major role in the processes of photosynthesis and respiration. These results agreed to with those obtained by Ibrahim Heba et al. (2018) and Rehab (2018).

\section{Conclusion}

To obtain the highest yield of fenugreek plant from the oil and seed yield of plants and feddan, as well as the highest value in the production of active substances such as mucilage, protein and trigonelline. The use of dissolved micronutrients in organic fertilizers (humic acid) with compost extract can reduce the costs of using chemical fertilizers by $50 \%$ and thus reduce the harmful impact on the environment and the human being.

\section{References}

Abdel Moneim, E. S., Ahmed Heba, E. 
and Abdelrahim A. M. (2008), "The chemical composition of fenugreek (Trigonella foenum graceum L.) and the antimicrobial properties of its seed oil Gezira", Journal of Engineering and Applied Science, Vol. 3 No. 2, pp. 52-71.

Aishwath, O. P., Meena, R. D., Jain, D., Dubey, P. N., Harisha, C. B., Mishra, B. K. and Ganeshamurthy, A. N. (2018), "Role of micronutrients on morpho-physiological, and nutritional parameters including diseases suppression of fenugreek", International Journal of Seed Spices, Vol. 8 No. 2, pp. 2431

Alaghemand, S., Ayyubi, H., Hasanpour, E., Olfati, Jamal-Ali, Saadatian, M. and Karimi, H. (2017), "Effects of organic fertilizers on growth and biochemical characteristics of fenugreek", Acta Agriculturae Slovenica, Vol. 109 No. 2, pp. 197203.

Amal, G. A., Magda, H. M., Nabila, M. Z., Hassanein, M. S. and Mirvat, E. G. (2015), "Effect of foliar application of bio and micronutrients fertilizer on increasing productivity of fenugreek yield", International Journal of ChemTech Research, Vol. 8 No. 9, pp. 43-53.

Atiyeh, R. M., Lee, S., Edwards C. A. (2002), "The influence of humic acids derived from earthwormprocessed organic wastes on plant growth", Bioresource Technology, Vol. 84 No. 1, pp. 7-14.
Ezz El-Din Azza, A. and Hendawy, S. F. (2010), "Effect of dry yeast and compost tea on growth and oil content of Borago Officinalis plant", Research Journal of Agriculture and Biological Sciences, Vol. 6 No. 4, pp. 424-430.

Baloch, Q. B., Chachar, Q. I. and Tareen, M. N. (2008), "Effect of foliar application of macro and micro nutrients on production of green chilies (Capsicum annuum L.)", Journal of Agricultural Technology, Vol. 4 No. 2, pp. 177-184.

Bernal, M., Cases, R., Picorel, R. and Yruela, I. (2007), "Foliar and root $\mathrm{Cu}$ supply affect differently $\mathrm{Fe}$ and Zn-uptake and photosynthetic activity in soybean plants", Environmental and Experimental Botany, Vol. 60, pp. 145-150.

Boghdady, M. S. (2017), "Role of micronutrients in improving yield and quality of seeds in fenugreek plants (Trigonella foenim graecum L.)", Egyptian Journal of Agronomy, Vol. 39 No. 3, pp. 267-277.

Bordia, A., Verma, S. K. and Srivastava, K. C. (1997), "Effect of ginger (Zingiber officinale Rosc.) and fenugreek (Trigonella foenumgraecum L.) on blood lipids, blood sugar and platelet aggregation in patients with coronary artery disease", Prostaglandins, Leukotrienes and Essential Fatty Acids, Vol. 56 No. 5, pp. 379-384.

Bukhari, S. B., Bhanger M. I. and 
Memon S. (2008), "Antioxidative activity of extracts from Fenugreek seeds (Trigonella foenumgraecum)", Pakistan Journal of Analytical \& Environmental Chemistry, Vol. 9 No. 2, pp. 78-83.

Chhibba, I. M., Nayyar, N. K. and Kanwar, J. S. (2007), "Influence of mode and source of applied iron on fenugreek (Trigonella corniculata, L.) in a Typic Ustochrept in Punjab, India", International Journal of Agriculture and Biology, Vol. 9 No. 2, pp. 245-256.

Ke, F., Yadav, P. K., Ju, L. Z. (2012), "Herbal Medicine in the Treatment of Ulcerative Colitis", Saudi Gastroenterology Association, Vol. 18 No. 1, pp. 3-10.

Abd-Elghany Gehan, G., El-Shazly Mona, M. and Hashem Hanan, A. E. A. (2017), "Water management for the fenugreek plant and its response to bio-fertilization In North Sinai", Egyptian Journal of Applied Science, Vol. 32 No. 12 B, pp. 494515.

Gharib, F. A., Moussa, L. A. and Massoud, O. (2008), "Effect of compost and bio fertilizers on the growth, yield and essential oil of sweet Marjoram (Majorana hortensis) plant", International Journal of Agriculture And Biology, Vol. 10, pp. 381-387.

Gorham, G. (1986), "Reversed-phase, ion-pair high-performance liquid chromatographic separation of aminoethanol, choline and related compounds, and a direct, quantitative high-performance liquid chromatographic assay for choline in plants", Journal of Chromatography A, Vol. 362, No. 2, pp. 243-253.

Hadi, S. T., Abed, M. M. and Fadhil, N. J. (2018), "Chemical composition of Trigonella foenum-graecum seeds and inhibitory activity of their seeds oil against some microbes", International Journal of Life Sciences and Biotechnology, Vol. 1 No. 2, pp. 75-83.

Haouala, R., Hawala, S., El-Ayeb, A., Khanfir, R. and Boughanmi, N. (2008), "Aqueous and organic extracts of Trigonella foenumgraecum L. inhibit the mycelia growth of fungi", Journal of Environmental Sciences, Vol. 20, pp. 1453-1457.

Ibrahim Heba, A. K., Khater Rania, M. R. and Hegab Rehab, H. (2018), "Evaluate the effect of compost tea and some chelated micronutrients forms on black cumin productivity", SN Applied Sciences, Vol. 1, Article number: 28

Ibrahim, H. A. K., 2019 "Effect of foliar application of compost water extract, humic acid, EDTA and micronutrients on the growth of fenugreek plants under sandy soil condition", International Journal of Environmental Science and Technology, Vol. 16, pp. 7799-7804.

Kaviarasan, S., Naik, G. H., 
Gangabhagirathi, R., Anuradha, C. V. and Priyadarsini, K. I. (2007), "In vitro studies on antiradical and antioxidant activities of fenugreek (Trigonella foenum-graecum) seeds", Journal of Agricultural and Food Chemistry, Vol. 103, pp. 3137.

Khan, R. U., Rashid, A. and Khan, M. S. (2010), "Impact of humic acid and chemical fertilizer application on growth and grain yield of rainfed wheat (Triticum aestivum L.)", Pakistan Journal of Agricultural Sciences, Vol. 23, pp. 113-121

Haggag Laila, F., Merwad, M. A., Shahin, M. F. M., Hoballah, E. M. and Mahdy, H. A. (2014), "Influence of mineral NPK and compost tea as soil applications on growth of "aggizi" olive seedlings under greenhouse condition", Middle East Journal of Agriculture Research, Vol. 3 No. 4, pp. 701-706.

Lal, G., Singh, B., Mehta, R. S. and Maheria, S. P. (2015), "Performance of fenugreek (Trigonella foenumgraecum L.) as influenced by sulphur and zinc", International Journal of Seed Spices, Vol. 5 No. 1, pp. 29-33.

Page, A. L., Miller, R. H. and Keeny, D. R. C. (1981), Microbiological properties, Second Edition, Agronomy J. 9, American Society of Agronomy, Inc., Soil Science Society of America, Inc. Publication, Madison, Wisconsin, USA.
Pariari, A., Khan, S. and Imam, M. N. (2009), "Influence of boron and zinc on increasing productivity of Fenugreek seed (Trigonella foenumgraecum L.)", Journal of Crop and Weed, Vol. 5 No. 2, pp. 57-58.

Kumar, R., Patil, S., Patil, M. and Paschapur, M. (2009), "Isolation and evaluation of disintegrant properties of fenugreek seed mucilage", International Journal of PharmTech Research, Vol.1 No.4, pp. 982-996.

Hegab Rehab, H. (2018), "Effect of foliar application of micronutrients and compost tea on chemical composition and the productivity of fenugreek plants under Baloza North Sinai conditions", Journal of Soil Sciences and Agricultural Engineering, Vol. 9 No. 9, pp. 403410.

Scheuerell, S. (2003), "Understanding how compost tea can control disease", Bio Cycle, Vol. 44 No. 2, pp. 20-25.

Sharma, S., Sharma, Y. and Balai, C. M. (2014), "Yield attributes and yield of fenugreek (Trigonella foenumgraecum L.) under different levels of phosphorus, molybdenum and inoculation of PSB", Agriculture Update, Vol.9 No. 3, pp. 301-305.

Sindhu, G., Ratheesh, M., Shyni, G. L., Nambisan, B. and Helen, A. (2012), "Anti-inflammatory and antioxidative effects of mucilage of Trigonella foenum-graecum 
(Fenugreek) on adjuvant induced arthritic rats", International Immunopharmacology, Vol. 12 No. 1, pp. 205-211.

Srinivassan, K. (2006), "Fenugreek (Trigonella foenim-graecum L.): A review of health beneficial physiological effects", Food Reviews International, Vol. 22, pp. 203-224.

Bae, S. H. (2014), "Diets for constipation", Pediatric Gastroenterology, Hepatology \& Nutrition, Vol. 17 No. 4, pp. 203208.
Zuppa, A. A., Sindico, P., Orchi, C., Carducci, C., Cardiello, V. and Romagnoli, C. (2010), "Safety and efficacy of galactogogues: substances that induce, maintain and increase breast milk production", Journal of Pharmacy \& Pharmaceutical Sciences, Vol. 13 No. 2, pp. 162-174. 